\title{
DISTRIBUTION OF IMMUNOREACTIVE ATRIAL AND BRAIN NATRIURETIC PEPTIDES IN THE HEART OF THE NEWT, CYNOPS PYRRHOGASTER
}

\author{
Yoko KASUYA, Tohru HIROHAMA and HaRUko UEMURA \\ Biological Laboratory, Kanagawa Dental College, Yokosuka, Kanagawa 238
}

Received for publication September 25, 1991 and in revised form November 14, 1991

\begin{abstract}
The distribution of immunoreactive (ir-) atrial natriuretic peptide (ANP) and brain natriuretic peptide (BNP) was studied immunohistochemically and immunoelectronmicroscopically in the heart of the newt, Cynops pyrrhogaster. The difference in immunostaining for ANP and BNP indicated that the heart of the newt contains two peptides, and that they are immunologically related to mammalian ANP and BNP, respectively. Immunoreactivity for ANP was stronger than that for BNP in the atrium, postcaval vein and sinus venosus of all specimens, while immunoreactivity for BNP was similar to or stronger than that for ANP in the ventricle of most specimens. Ir-ANP and ir-BNP appeared to be colocalized in many cardiocytes in the atrial wall and in some of ventricular cardiocytes. The double protein A-gold labeling technique revealed the granules showing immunoreactivity only for ANP and those showing only for BNP in the same cardiocyte of the atrium and ventricle. In addition, there were some granules showing coexistence of ir-ANP and ir-BNP.
\end{abstract}

Atrial natriuretic peptides (ANPs) have been isolated from heart extracts of several mammalian species. Using an antiserum raised against synthetic ANP, immunoreactive ANP (ir-ANP) has been detected by radioimmunoassay and immunohistochemistry not only in the heart, but also in the brain, peripheral nervous system, vena cava, and various other tissues in mammals (for review, see 3). Furthermore, the presence of ir-ANP has been described in many species of non-mammalian vertebrates using antisera raised against mammalian ANPs (2, 4-6, $10,11,13,14,19,20)$. However, no report has been presented on the presence of ir-ANP in urodeles.

Meanwhile, a natriuretic peptide, similar to ANP in primary structure, has been isolated from the porcine brain and designated as brain natriuretic peptide (BNP) $(16,17)$. This brain peptide was shown by radioimmunoassay to be present in the hearts of pigs (9), rats (12) and humans (18). However, no studies of BNP have been conducted in non-mammalian vertebrates.

The present study was undertaken to determine

This study was supported in part by a Grant-in-Aid for Scientific Research from the Japan Ministry of Education, Science and Culture (02640587) to Dr. H. Uemura. whether ANP- and BNP-like peptides can be detected in the cardiocytes of the urodele, Cynops pyrrhogaster and, if so, whether or not they are colocalized in the same cardiocytes and further in the same secretory granules.

\section{MATERIALS AND METHODS}

Twelve newts (Cynops pyrrhogaster) $(9.5-11.0 \mathrm{~cm}$ in total length) of both sexes, which were collected in early summer (May-July), were used. The animals were maintained in an aquarium $(\mathrm{H}, 32 \mathrm{~cm} ; \mathrm{W}, 61 \mathrm{~cm} ; \mathrm{D}$, $42 \mathrm{~cm}$ ). Half of the area of the bottom of the aquarium was a pool with a $5 \mathrm{~cm}$ depth of water and the other half was a terrestrial area composed of coarse sand. Newts were kept in the aquarium for more than 1 week before use. Bovine liver was given as food every two days.

Antisera As the primary structures of newt ANP and BNP are not known, we used antisera raised against $\alpha$ human ANP and porcine BNP [1-26] (Peptide Institute, Inc., Osaka) in rabbits. The anti-ANP antiserum had a $55 \%$ cross-reactivity with $\alpha$-rat ANP, but did not cross-react with porcine BNP [1-26]. The cross-reactivity of the anti-BNP antiserum was less than $0.1 \%$ with $\alpha$-human ANP and $\alpha$-rat ANP. 
In a preliminary experiment, preabsorption of the anti-ANP antiserum with synthetic porcine BNP resulted in no detectable changes in immunostaining, as compared with the staining obtained with the untreated anti-ANP antiserum. Preabsorption of the anti-BNP antiserum with synthetic rat ANP [3-28] yielded a slight decrease in immunostaining, as compared with that obtained with untreated antiserum. Therefore, in order to eliminate any possible crossreaction with heterologous antigens, anti-ANP antiserum $(1: 1000)$ was preabsorbed with synthetic porcine BNP $(10 \mu \mathrm{g} / \mathrm{ml})$ for both immunohistochemistry and immuno-electron microscopy, and anti-BNP antiserum $(1: 1000)$ was preabsorbed with rat ANP $(10 \mu \mathrm{g} / \mathrm{ml})$ for the former technique and with $\alpha$-human ANP $(10 \mu \mathrm{g} / \mathrm{ml})$ for the latter technique, respectively. These antisera were used as primary antibodies for immunostaining and immunolabeling. Incubation for preabsorption was 30-60 min duration at room temperature and then overnight at $4{ }^{\circ} \mathrm{C}$. The incubated mixture was then centrifuged at $3000 \mathrm{rpm}$ for $20 \mathrm{~min}$ at $4^{\circ} \mathrm{C}$, and the supernatant was used.

As control, the following sera were used instead of the primary antisera: anti-ANP antiserum $(1: 1000)$ preabsorbed with rat ANP $(10 \mu \mathrm{g} / \mathrm{ml})$ for immunohistochemistry, and preabsorbed with $\alpha$-human ANP $(10 \mu \mathrm{g} / \mathrm{ml})$ for immuno-electron microscopy, and anti-BNP antiserum $(1: 1000)$ preabsorbed with porcine BNP $(10 \mu \mathrm{g} / \mathrm{ml})$ for both immunohistochemistry and immuno-electron microscopy.

Immunohistochemistry Nine newts were used for this study. After animals were anesthetized with $0.1 \%$ ethyl m-aminobenzoate methanesulfonate (Nacalai Tesque, Inc., Kyoto) in tap water, the heart of each specimen was rapidly removed and fixed in Bouin's fluid at about $5^{\circ} \mathrm{C}$ for $24 \mathrm{hr}$ and then embedded in Paraplast. Serial horizontal sections were made with a thickness of $6 \mu \mathrm{m}$.

Deparaffinized sections were immunostained by the avidin-biotin-peroxidase complex (ABC) method (7) with a slight modification. To block endogenous peroxidase activity, hydrated sections were soaked in $3 \% \mathrm{H}_{2} \mathrm{O}_{2}$ in methanol for $30 \mathrm{~min}$ at $4^{\circ} \mathrm{C}$. The sections were then rinsed in $0.01 \mathrm{M}$ phosphate-buffered saline (PBS; $\mathrm{pH} \mathrm{7.3)} \mathrm{for} 15 \mathrm{~min}$ and incubated in normal goat serum $(1: 66)$ in PBS for 20 min to eliminate background staining. This procedure was followed by incubation with the primary antiserum $(1: 1000)$ in PBS for $60-90 \mathrm{~min}$. After the incubation, sections were washed in PBS for 20 min and further incubated with biotinylated antibodies raised in goat against rabbit IgG (1:200) in PBS for 30-45 min. After washing in PBS for $20 \mathrm{~min}$, sections were immersed in the Vec- tastain $\mathrm{ABC}$ reagent $(1: 100$; Vector Laboratories, Inc., Burlingame, Calif.) in PBS for 60-90 min. Each incubation was conducted in a moist chamber at room temperature (around $27^{\circ} \mathrm{C}$ ), unless otherwise stated. For the peroxidase reaction, slides were treated with $0.05 \%$ 3,3-diaminobenzidine tetrahydrochloride (DAB; Dojindo, Kumamoto) in $0.05 \mathrm{M}$ Tris-HCl buffer ( $\mathrm{pH} 7.6$ ) that contained $0.0084 \%$ $\mathrm{H}_{2} \mathrm{O}_{2}$ for $13 \mathrm{~min}$, and then they were washed in tap water for $7 \mathrm{~min}$ and in distilled water for $5 \mathrm{~min}$. The sections were dehydrated through an ethanol series, cleared in xylene, and mounted with acrylic resin (Malinol; Muto Pure Chemicals, Co., Ltd., Tokyo). Immuno-electron microscopy

Three specimens were used for this study. The heart was dissected out immediately after decapitation. Atrium and ventricle were cut into small pieces (less than $1 \mathrm{~mm}^{3}$ ) and fixed for $2 \mathrm{hr}$ at $4^{\circ} \mathrm{C}$ in a $2.0 \%$ glutaraldehyde- $2.5 \%$ paraformaldehyde mixture dissolved in $0.1 \mathrm{M}$ cacodylate buffer at $\mathrm{pH}$ 7.2. After being rinsed in the same buffer for $24 \mathrm{hr}$, the tissues were dehydrated through a series of graded ethanol, transferred to acetone, and then embedded in Spurr resin (Polysciences, Inc., Warrington, Pennsylvania). Ultrathin sections were cut and mounted on uncoated nickel grids.

Ultrathin sections were labeled by the postembedding double protein A-gold technique (1) with a slight modification. First, one face of a section was 1) in-

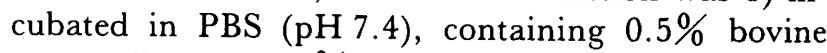
serum albumin $(0.5 \%$ BSA-PBS), for $30 \mathrm{~min}$ at room temperature, 2) incubated in anti-ANP antibody (1: 1000 ) overnight at $\left.4^{\circ} \mathrm{C}, 3\right)$ washed (10 min, 3 times) with $\mathrm{PBS}, 4)$ incubated in protein A-gold complex (Janssen Biotech N. V., Olen, Belgium) $(1: 20$; gold particle, $20 \mathrm{~nm}$ ) for $30 \mathrm{~min}$ at room temperature, 5) washed with PBS, and rinsed in distilled water. After drying, another face of the section was incubated in the same way, but anti-BNP antiserum $(1: 1000)$ and protein A-gold complex (1:20; gold particle, $10 \mathrm{~nm})$ were used in step 2) and 4), respectively. The sections were then stained with both uranyl acetate and lead citrate, and examined under an electron microscope. Antisera and protein A-gold complex were diluted with $0.5 \%$ BSA-PBS.

\section{RESULTS}

\section{Immunohistochemical observations.}

The anti-ANP and anti-BNP antisera, preabsorbed with synthetic rat ANP and porcine BNP, respectively, showed no indication of immunoreaction. 

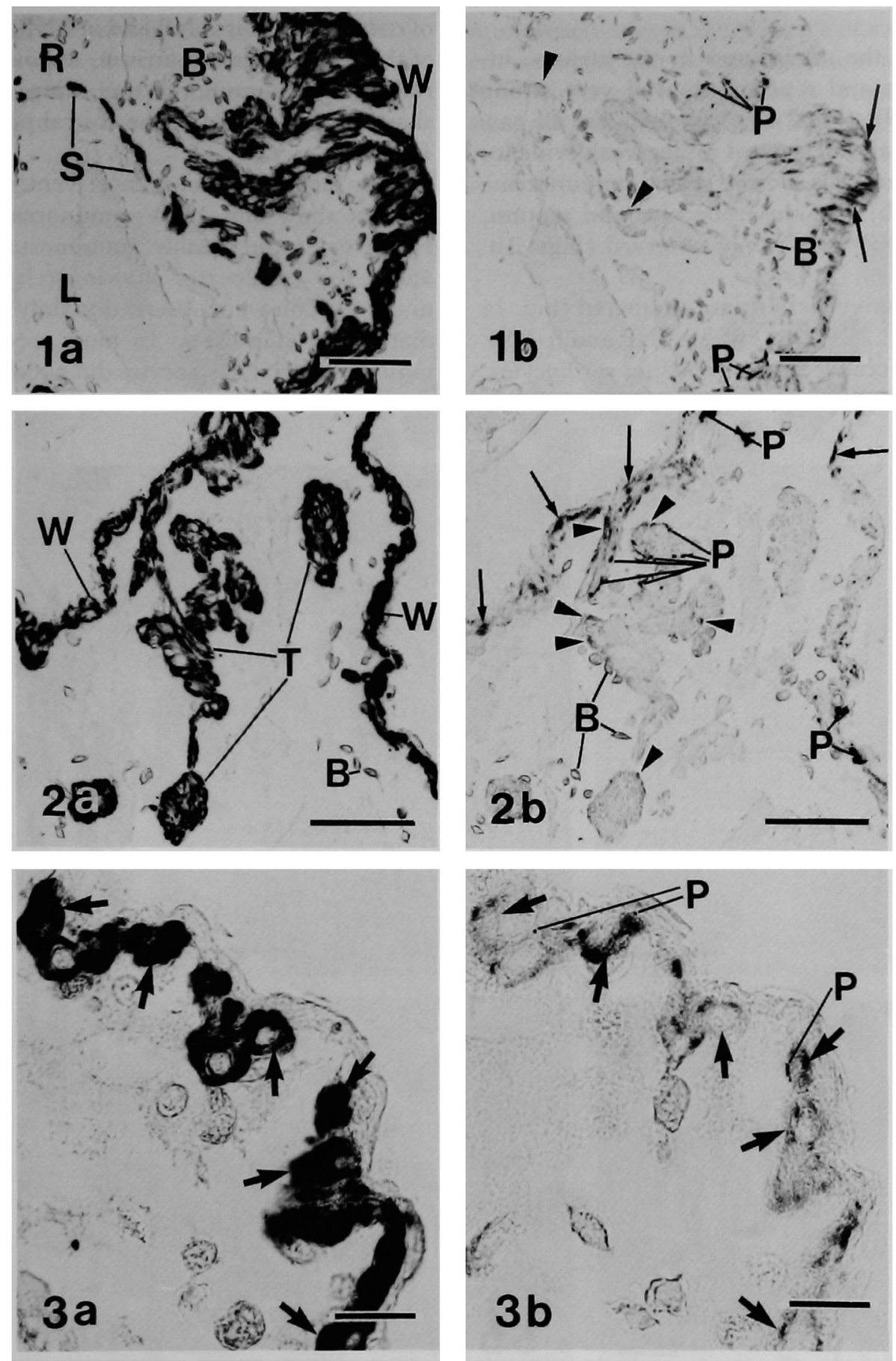

Figs. 1a, b. Two horizontal, consecutive sections at the medio-ventral level of the middle portion of the atrium of the newt. a. Nearly all cardiocytes of the wall $(W)$ and of the septum $(S)$ show strong immunoreaction for ANP. b. Most atrial cardiocytes of the wall show relatively weak immunoreaction for BNP, but some cells are strongly immunostained (arrows). Immunoproducts are barely visible in a few cells (arrowheads) of the septum. $B$ : blood corpuscle, showing non-specific reaction, $L:$ left atrium, $P$ : pigment, $R$ : right atrium. $\times 109 \quad B a r=100 \mu \mathrm{m}$.

Figs. 2a, b. Two horizontal, consecutive sections at the same level as in Fig. 1, of the rostral portion of the right atrium. a. Nearly all cardiocytes of the wall $(W)$ and of the trabeculae $(T)$ show strong immunoreaction for ANP. b. Most atrial cardiocytes of the wall show weak immunoreaction for BNP, but some cells are strongly immunostained (arrows). Weak immunoreaction is visible in some cells (arrowheads) of the trabeculae. B: blood corpuscle, showing non-specific reaction, $P$ : pigment. $\quad \times 139 \quad B a r=100 \mu \mathrm{m}$.

Figs. 3a, b. Two horizontal, consecutive sections at the dorsal level of the rostral portion of the right atrium. Cardiocytes (arrows) are immunoreactive for both ANP (a) and BNP (b), although the extent of immunoreactivity is weaker in the latter. $P$ : pigment. $\times 554$ Bar $=20 \mu \mathrm{m}$. 


\section{Atrium}

Nearly all of the cardiocytes in the atrium, including trabeculae and septum, showed very strong staining for ir-ANP (Figs. 1a, 2a). Almost all cardiocytes of the atrial wall showed rather weak evidence of ir-BNP, but some cells showed strong immunoreactivity (Figs. 1b, 2b). In the trabeculae and septum, cells showed ir-BNP were rarely observed (Figs. 1b, 2b).

When consecutive sections are compared (Fig. 1a versus $1 b$, and Fig. $2 a$ versus $2 b$ ), ir-ANP and ir-BNP appeared to be localized in the same cardiocytes. Magnified microphotographs give conclusive evidence of coexistence of ir-ANP and ir-BNP in the cardiocytes of the entire region of atrium, although ir-BNP shows rather weak immunoreaction. Fig. 3 is one example showing coexistence in the rostral portion of atrium.

Ventricle

In most specimens, most ventricular cardiocytes did not show any ANP immunoreactivity (Fig. 4a). However, some weakly immunostained cardiocytes and a few cardiocytes showing relatively strong immunoreaction were observed mainly in the subepicardial region (Fig. 5a). In most specimens, although most ventricular cardiocytes did not show any BNP immunoreactivity, some of the ventricular cardiocytes
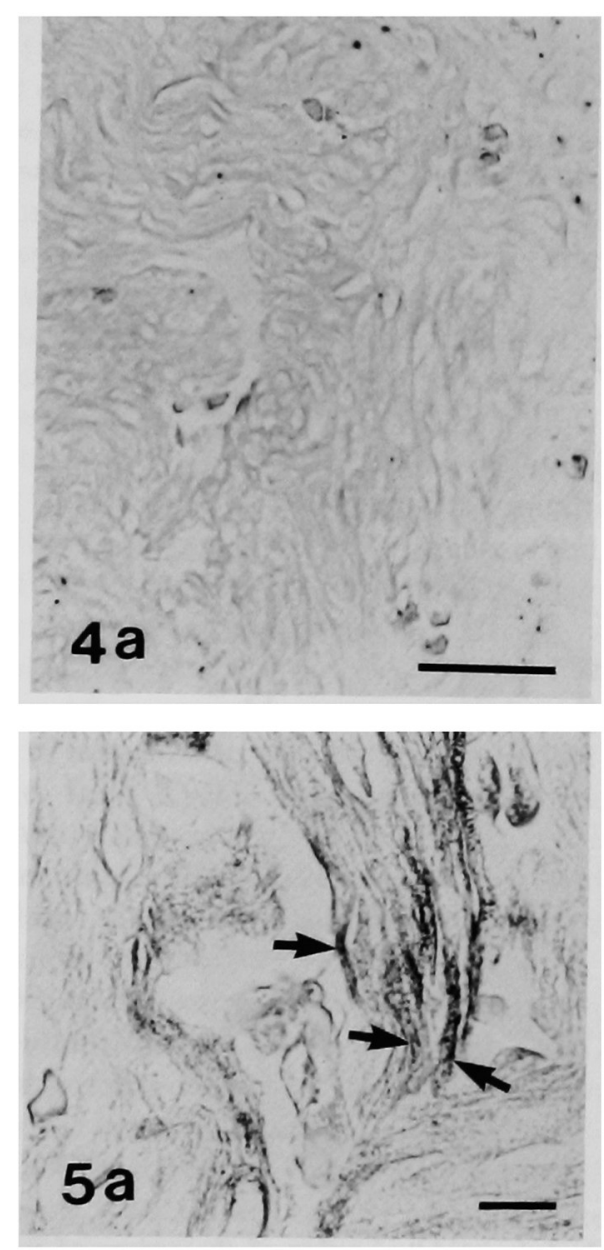
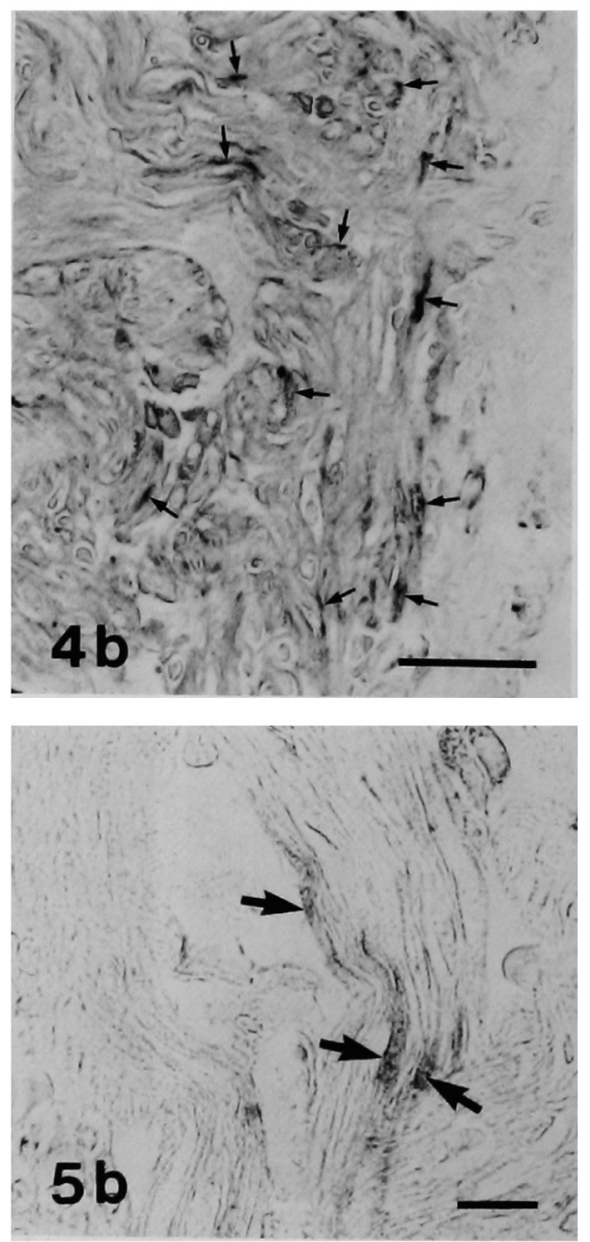
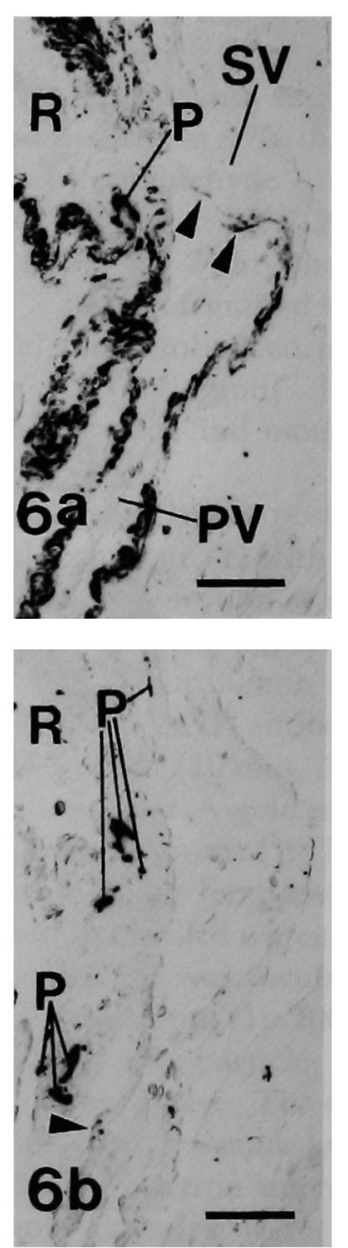

Figs. 4a, b. Two horizontal, consecutive sections at the ventral level of the middle portion of ventricle. a. Cardiocytes do not show any immunoreaction for ANP in this specimen. Blood corpuscles show non-specific reaction. b. Several cardiocytes (arrows) show obvious immunoreaction for $\mathrm{BNP}$ in the subepicardial region. $\times 140 \quad B a r=100 \mu \mathrm{m}$.

Figs. 5a, b. Two horizontal, consecutive sections at the ventral level of the caudal portion of the ventricle. Cardiocytes (arrows) are immunoreactive for both ANP (a) and BNP (b). $\times 396 \quad B a r=20 \mu \mathrm{m}$.

Figs. 6a, b. Two horizontal, consecutive sections of the sinus venosus $(S V)$ and the postcaval vein $(P V)$. a. The wall of the postcaval vein shows immunoreaction for ANP. In a few cells (arrowheads) of the sinus venosus, immunoreactivity for ANP is observed. b. Immunoreactivity is scarcely visible in a cell (arrowhead) of the wall of the postcaval vein, and not in the sinus venosus. $P$ : pigment, $R$ : right atrium. $\quad \times 86 \quad B a r=100 \mu \mathrm{m}$. 
showed obvious BNP immunoreactivity (Fig. 4b). Such positive cells were observed more frequently in the subepicardial region than in the other regions.

In a comparison between ANP and BNP im- munoreactivities in the ventricle of 8 specimens observed, we found that they were present to almost the same extent in 4 specimens, and in 1 specimen ANP was stronger than that of BNP (Figs. 5a, b). However, in
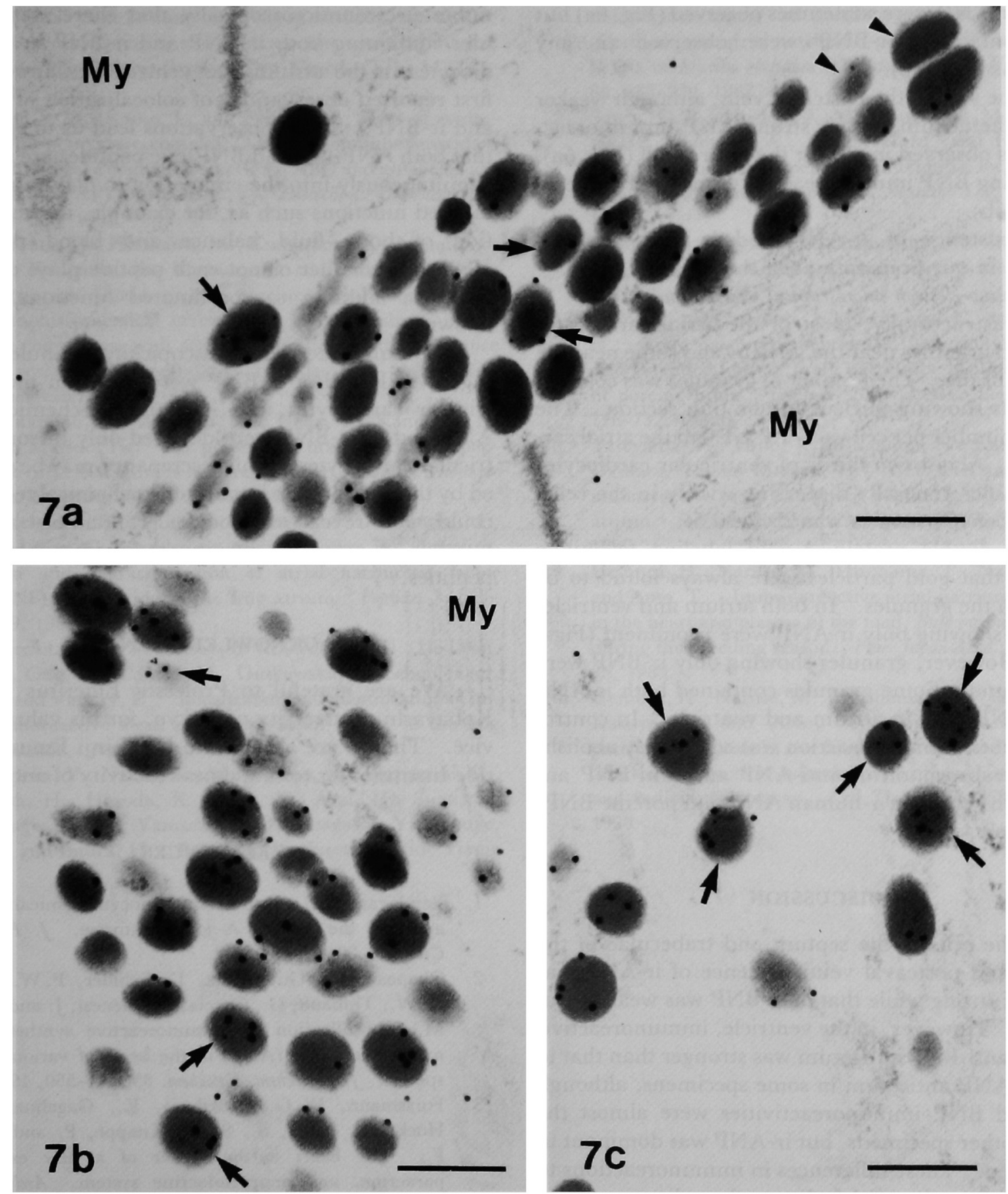

Figs. 7a-c. Intragranular localization of ir-ANP and ir-BNP in the atrial (a, b) and ventricular (c) cardiocytes revealed by the double protein A-gold method. Large gold particles ( $20 \mathrm{~nm}$ in diameter) and small gold particles (10 nm in diameter) demonstrate irANP and ir-BNP, respectively. Granules showing both ir-ANP and ir-BNP (arrows), and those showing only ir-ANP are found, but those showing only ir-BNP (arrowheads) are rarely found. My: myofibrils. $\quad \times 54,000 \quad B a r=300 \mathrm{~nm}$. 
3 specimens, BNP immunoreactivity was slightly stronger than ANP immunoreactivity (Figs. 4a, b).

Some cells were immunoreactive to both antiANP and anti-BNP antisera (Figs. 5a, b).

Other tissues

In the wall of the sinus venosus, cells containing distinct ir-ANP were sometimes observed (Fig. 6a) but none containing ir-BNP were observed in any specimens (Fig. 6b).

In the wall of the postcaval vein, although weaker than in the atrium, rather strong ANP immunoreactivity was observed in almost the entire wall (Fig. 6a). Convincing BNP immunoreactivity was rarely observed (Fig. 6b).

Coexistence of ir-ANP and ir-BNP was not observed in our preparations of these tissues.

II. Immuno-electron microscopical observations

Ultrastructurally, most of the atrial cardiocytes contained granules near the nucleus and some near the cell membrane. The number of granules was counted in 30 cells showing nucleus in one thin section. The average number per cell was $71.7 \pm 1.0$ in the atrial cardiocytes. About two thirds of ventricular cardiocytes had granules generally dispersing widely in the cells; the number of granules was $25.3 \pm 0.5$.

The double protein A-gold labeling technique revealed that gold particles were always found to be located in the granules. In both atrium and ventricle, granules showing only ir-ANP were prominent (Figs. 7a-c). However, granules showing only ir-BNP were rarely found. Some granules contained both ir-ANP and ir-BNP both in atrium and ventricle. In control experiments, immunoreaction was completely abolished by preabsorption of anti-ANP and anti-BNP antisera with synthetic $\alpha$-human ANP and porcine BNP, respectively.

\section{DISCUSSION}

In the cells of the septum and trabeculae of the atrium, and postcaval vein, evidence of ir-ANP was relatively strong while that of ir-BNP was weak or not detected. However, in the ventricle, immunoreactivity to the anti-BNP antiserum was stronger than that to the anti-ANP antiserum in some specimens, although ANP and BNP immunoreactivities were almost the same in other specimens, but ir-ANP was dominant in 1 specimen. These differences in immunoreactions to both antisera strongly indicate that there are two different peptides, similar to $\alpha$-human ANP and porcine $\mathrm{BNP}$, respectively, in the newt heart.

It has been demonstrated immunohistochemically that the pattern of distribution of ir-BNP is distinct from that of ir-ANP in the porcine spinal cord (8) and in the rat brain (15). However, no mention was made in these earlier reports about the colocalization of irANP and ir-BNP. We found immunohistochemically that the same cardiocytes showed immunoreactivity to both anti-ANP and anti-BNP antisera and, further immuno-electronmicroscopically that there were granules containing both ir-ANP and ir-BNP in the cardiocytes in the atrium and ventricle. Ours are the first reported observations of colocalization of ir-ANP and ir-BNP. These observations lead us to speculate that both ANP-like and BNP-like peptides are secreted simultaneously into the circulation to play some coordinated functions such as, for example, in the regulation of body fluid balance and blood pressure. However, whether or not each peptide plays different roles, in addition to coordinated functions, is not known.

Immuno-electronmicroscopically, granules showing ir-ANP and/or ir-BNP were found in most ventricular cardiocytes, but immunohistochemically irANP and/or ir-BNP were detected only in some ventricular cardiocytes. This discrepancy may be explained by the fact that the immunohistochemical technique could not reveal cardiocytes containing a small number of granules showing these immunoreactive peptides.

\section{ACKNOWLEDGMENTS}

We are grateful to Professor Emeritus Hideshi Kobayashi, University of Tokyo, for his valuable advice. Thanks are also due to Dr. Junji Emura, Peptide Institute, for testing cross-reactivity of antibodies.

\section{REFERENCES}

1. Bendayan, M.: Double immunocytochemical labeling applying the protein A-gold technique. J. Histochem. Cytochem. 30; 81-85, 1982.

2. Chapeau, C., Gutkowska, J., Schiller, P. W., Milne, R. W., Thibault, G., Garcia, R., Genest, J. and Cantin, M.: Localization of immunoreactive synthetic atrial natriuretic factor (ANF) in the heart of various animal species. J. Histochem. Cytochem. 33; 541-550, 1985.

3. Forssmann, W. G., Nokihara, K., Gagelmann, M., Hock, D., Feller, S., Schulz-Knappe, P. and Herbst, F.: The heart is the center of a new endocrine, paracrine, and neuroendocrine system. Arch. Histol. Cytol. 52 (Suppl); 293-315, 1989.

4. Gilles, J., Netchitailo, P., Leboulenger, F., Cantin, M., Pelletier, G. and Vaudry, H.: Localization and characterization of the $\mathrm{N}$-terminal fragment of atrial natriuretic factor (ANF) precursor in the frog heart. Pep- 
tides $11 ; 199-204,1990$.

5. Hirohama, T., Uemura, H., Nakamura, S. and Aoto, T.: Atrial natriuretic peptide (ANP)-immunoreactivity and ultrastructures of cardiocytes in fish. Zool. Sci. 5; 833-845, 1988.

6. Hirohama, T., Uemura, H., Nakamura, S., Naruse, M. and Aoto, T.: Ultrastructure and atrial natriuretic peptide (ANP)-like immunoreactivity of cardiocytes in the lar$\mathrm{val}$, metamorphosing and adult specimens of the Japanese toad, Bufo japonicus formosus. Dev. Growth. Differ. 31; 113$121,1989$.

7. Hsu, S. M., Raine, L. and Fanger, H.: Use of avidinbiotin-peroxidase complex (ABC) in immunoperoxidase techniques: a comparison between $\mathrm{ABC}$ and unlabeled antibody (PAP) procedures. J. Histochem. Cytochem. 29; 577-580, 1981.

8. Kawata, M., Hirakawa, M., Kumamoto, K., Minamino, N., Kangawa, K., Matsuo, H. and Sano, Y.: Brain natriuretic peptide in the porcine spinal cord: an immunohistochemical investigation of its localization and the comparison with atrial natriuretic peptide, substance $P$, calcitonin gene-related peptide, and enkephalin. Neuroscience 33; 401-410, 1989.

9. Minamino, N., Aburaya, M., Ueda, S., Kangawa, K. and Matsuo, H.: The presence of brain natriuretic peptide of 12,000 daltons in porcine heart. Biochem. Biophys. Res. Commun. 155; 740-746, 1988.

10. Netchitailo, P., Feuilloley, M., Pelletier, G., Cantin, M., De Léan, A., Leboulenger, F. and Vaudry, H.: Localization and characterization of atrial natriuretic factor (ANF)-like peptide in the frog atrium. Peptides 7; 573$579,1986$.

11. Netchitailo, P., Feuilloley, L. M., Pelletier, G., De Léan, A., Ong, H., Cantin, M., Gutkowska, J., Leboulenger, F. and Vaudry, H.: Localization and identification of immunoreactive atrial natriuretic factor (ANF) in the frog ventricle. Peptides 9; 1-6, 1988.

12. Ogawa, Y., Nakao, K., Mukoyama, M., Shirakami, G., Itoh, H., Hosoda, K., Saito, Y., Arai, H., Suga, S., Jougasaki, M., Yamada, T., Kambayashi, Y., Inouye, K. and Imura, H.: Rat brain natriuretic peptide-Tissue distribution and molecular form. Endocrinology 126; 2225-2227, 1990.

13. Reinecke, M., Nehls, M. and Forssmann, W. G.: Phylogenetic aspects of cardiac hormones as revealed by immunocytochemistry, electronmicroscopy, and bioassay. Peptides 6 (Suppl 3); 321-331, 1985.

14. Reinecke, M., Betzler, D. and Forssmann, W. G.: Immunocytochemistry of cardiac polypeptide hormones (Cardiodilatin/atrial natriuretic polypeptide) in brain and hearts of Myxine glutinosa (Cyclostomata). Histochemistry 86; 233-239, 1987.

15. Saper, C. B., Hurley, K. M., Moga, M. M., Holmes, H. R., Adams, S. A., Leahy, K. M. and Needleman, P.: Brain natriuretic peptides: differential localization of a new family of neuropeptides. Neurosci. Lett. 96; 29-34, 1989.

16. Sudoh, T., Kangawa, K., Minamino, N. and Matsuo, H.: A new natriuretic peptide in porcine brain. Nature 332; 78-81, 1988a.

17. Sudoh, T., Minamino, N., Kangawa, K. and Matsuo, $\mathrm{H}$.: Brain natriuretic peptide-32: N-terminal six amino acid extended form of brain natriuretic peptide identified in porcine brain. Biochem. Biophys. Res. Commun. 155; 726-732, 1988b.

18. Tateyama, H., Hino, J., Minamino, N., Kangawa, K., Ogihara, T. and Matsuo, H.: Characterization of immunoreactive brain natriuretic peptide in human cardiac atrium. Biochem. Biophys. Res. Commun. 166; 1080-1087, 1990.

19. Uemura, H., Naruse, M., Hirohama, T., Nakamura, S. and Aoto, T.: Immunoreactive atrial natriuretic peptide in the heart and plasma of the toad, Bufo japonica formosus, during the breeding season. Proc. Japan Acad. [B] 65; 8486, 1989.

20. Uemura, H., Naruse, M., Hirohama, T., Nakamura, S., Kasuya, Y. and Aoto, T.: Immunoreactive atrial natriuretic peptide in the fish heart and blood plasma examined by electron microscopy, immunohistochemistry and radioimmunoassay. Cell Tissue Res. 260; 235-247, 1990. 